\title{
Organizational Commitment and Labor Satisfaction. Case: A University Organization in the State of Morelos. México
}

\author{
Ana Laura Uscanga Arévalo ${ }^{1}$, Augusto Renato Pérez $\mathrm{Mayo}^{2}$ \& Nohemí Roque Nieto ${ }^{3}$ \\ ${ }^{1}$ M.A.O. Academic Secretary of the Autonomous University of the State of Morelos, Mexico \\ ${ }^{2} \mathrm{PhD}$ Department of Studies of the organizations and Sociology of Organizations Faculty of Accounting, Management, \\ and Informatics, The Autonomous University of the State of Morelos, (Acronym UAEM), Mexico \\ ${ }^{3} \mathrm{PhD}$ Academic Coordinator of the Master in Organization Administration, Department of Studies of the organizations \\ and Sociology of Organizations Faculty of Accounting, Management, and Informatics, The Autonomous University of \\ the State of Morelos, Mexico \\ Correspondence: Augusto Renato Pérez Mayo, PhD Department of Studies of the organizations and Sociology of \\ Organizations Faculty of Accounting, Management, and Informatics, The Autonomous University of the State of Morelos, \\ (Acronym UAEM), Mexico.
}

Received: October 22, 2020

Accepted: January 20, $2021 \quad$ Available online: February 8, 2021

doi:10.11114/ijsss.v9i2.5154

URL: https://doi.org/10.11114/ijsss.v9i2.5154

\begin{abstract}
This article measures two organizational factors of importance for every organization: labor satisfaction and organizational commitment. The analysis is made under the perspective of the sociology of organizations: Frederick Herzberg's theory of the two factors of motivation (hygienic and motivational) and Meyer and Allen's model of the three components of organizational commitment (1990). The methodology is empirical, descriptive and quantitative. The study was carried out with a sample of 59 employees, classified as reliable personnel of the Academic Secretary of an Institution of Higher Education (IES) in the city of Cuernavaca, Morelos. The instruments used were two questionnaires emanated from the theory itself with the purpose of knowing aspects related to the two study variables. This instrument allowed to identify the types of organizational commitment and the levels of work satisfaction and satisfaction that exist in the university organization.
\end{abstract}

Keywords: labor satisfaction, organizational commitment, organizational behavior and motivation

\section{Introduction}

Since the beginning of the 20th century, humanity has experienced constant social, economic, political and cultural change. During this period, there was a transformation of paradigms and mental models, which affected both the ways of life of people and the nexus that the individual constitutes with the organization to which it belongs (Ramirez, Badii and Abreu, 2008). Similarly, human resources became the most valuable of all organizations, enlisting both tangible and intangible resources, making them work in an operational cycle and establishing the relationships that allow the organization to achieve its objectives (D'Alessio, 2015; Robbins and Coulter, 2012). However, it must be recognized that, in the current work environment, the future of the organizations lies in the responsibility of the managers who best know how to manage change. To lead change in organizations, there must be committed employees, those who represent the source of competitive advantage (Dessler, 1993).

As Ramírez, Badii and Abreu (2008) point out, one of the great problems currently faced by organizations is finding ways to motivate human resources to increase their performance in their work, as well as their satisfaction, commitment and interest in their work. By this, we mean that it is essential that the organization achieves that its staff is adequately motivated to achieve organizational and personal goals.

This study examines the particular case of the Central Academic Secretariat (SAC) of a Higher Education Institution (IES) in the city of Cuernavaca, Morelos, Mexico. This SAC has an organizational structure made up of the Directorates of Research and Graduate Studies, Higher Education, Secondary Education, Academic Relations, and Publications and Dissemination, in addition to the coordination of Academic Commissions and National and International Cooperation. 
This university is one of the fastest growing higher education institutions in the city of Cuernavaca, Morelos, a development that is reflected in the number of students enrolled per academic period. Despite the growth and the image that the institution has in the local and regional context, information flows within it in an informal manner about a certain degree of discontent. This relates to salary, working conditions, and some personnel administration policies. For example, salaries at the institution are low in relation to those at other universities of comparable quality in the city of Cuernavaca. On the other hand, during the 2018 fiscal year, the IES had complications paying salaries and benefits in a timely manner. Likewise, there were some situations of discontent and slight rotation in the SAC.

The first factor measured was organizational commitment, which according to Figueiredo, Grau, Gil and Garcia (2012), commitment refers to a set of moral principles and values characteristic of leaders who, in their eagerness to achieve the objectives set, firmly believe in the ideals of productivity, order and the systematization of organizational functions.

According to Caykoylu, Egri, Havlovic, and Bradley (2011), commitment is a set of beliefs, attitudes, and actions that reduce uncertainty and increase propensity for the future. Increased risk expectations would decrease motivation for work and disrupt the human relations system, which would affect the performance of each member.

For the purpose of this study, we took as our foundation the model of Meyer and Allen (1990), according to which commitment has three components that reflect a desire (emotional commitment), a need (continuity of commitment) and an obligation (normative commitment) to maintain employment in the organization. In effect, affective commitment is the greatest influence on workers and is the high tendency in most organizations to seek to promote organizational commitment, since employees bring value to the organization at an affable and familiar level (Meyer and Allen, 1990). What has been said so far implies that job satisfaction is an emotional response to objects or to what is related to the job or position, while organizational commitment is an emotional response to the organization (Porter, Steers, Mowday and Boulian, 1974).

To evaluate the second factor called job satisfaction, some elements of Herzberg's two-factor theory of motivation were taken, which states that there are two factors that guide people's behavior in work situations. First, there are the hygienic factors: also known as extrinsic or unsatisfactory factors, since they are located in the environment surrounding the person and cover the conditions in which they perform their work (Jongsoon, 2016). In second instance, there are the motivational factors, also known as intrinsic or satisfying factors, since they are related to the content of the job and the condition of the tasks that the individual performs. In addition, the motivational factors are under the control of the individual, since they are related to what he does and performs. The main motivational factors are: achievement, recognition, work itself, responsibility, promotion and growth (Manso Pinto, 2002). The presence of the hygienic factors serves mainly to avoid labor dissatisfaction, since they can bring tranquility, but not necessarily motivation and satisfaction at work. Motivational factors are strong determinants of job satisfaction (Vroom and Deci, 1979).

Similarly, that committed and satisfied employees are more likely to stay with their organizations, an uncommitted or unsatisfied workforce can generate higher costs to organizations, which is associated with higher turnover, lower productivity, eroded psychological well-being and poor physical health. As Herzberg suggests, the nature of the work, promotion opportunities, and salary satisfaction are important aspects that organizations should consider in order to manage these costs. In addition, organizations that are concerned about the well-being of employees and that consider employees' goals, values, and opinions to help them with the problems they face are likely to have employees who are energetic, enthusiastic, and passionate about their jobs, and who will therefore be committed to the organization (Zeynep, Rayton, and Rapti, 2017).

According to Robbins and Judge (2009), motivation is contained within and outside of man to achieve his expectations in a way that requires passion, encouragement or incitement to action. Furthermore, it is considered that motivation is a necessary factor in the study of the individual, understood as the thin line between employee satisfaction and commitment. Considering that employees can obtain their motivation in the form of material and non-material incentive. It should be emphasized that job satisfaction and organizational commitment are among the variables most studied by specialists in organizations. When both variables have a positive impact, better results are achieved and performance is increased and the relationship between employee and organization progresses. To achieve this, it is necessary to identify the factors that concern the variables; it is important to carry out specific studies that evaluate these variables, with the purpose of observing the attributes that concern the changes in the behavior of the employees and so that the organization can intervene in the benefit of both parts.

\section{Literature Review. Concepts and Theories of Organizations}

\subsection{Organizational commitment}

Organizational commitment can be understood as the extent to which individuals identify psychologically with the organization in which they work, according to Giacalone and Jurkiewicz (2010). 
According to Mowday, Porter, and Steers (1982), it can be understood that organizational commitment refers to the link between the worker and the employing, contracting organization. That is, a link with the employing organization and not with the work itself, or a particular part of the organization. The two main points of view about how the bond is formed are known as continuity and emotional commitment.

\subsection{Labor Satisfaction}

Locke (1976), identified job satisfaction as the emotional state that comes from the evaluation of an individual's actual experiences on the job. His research was explored through evaluations that were applied to employees, which, in turn, was limited to dimensions that he considered part of satisfaction, caused by the idea that work attitudes affected productivity and performance.

Job satisfaction according to Eagly and Chaiken (1993) refers to "an internal state that is expressed by affectively and/or cognitively evaluating a job experienced with some degree of favor or disfavor" (p.86).

According to Spector (1997), job satisfaction is defined as:

"an individual's general feeling about their work and attitudes about various aspects or facets of their work, as well as an attitude and perception that could eventually affect the degree of fit between the individual and the organization" (p.2). In other words, it is "the extent to which people like (satisfaction) or dislike (dissatisfaction) their jobs" (Spector, 1997, p.2).

\subsection{Organizational Theories}

The School of Organizational Behavior is based on discovering the limitations of human rationality. Likewise, it defines the administrative man as a being who behaves with relative rationality and who seeks satisfactory results (Casaux, 2015). According to Casaux (2015), the most widely used theories for the study of the variables of organizational commitment and job satisfaction are those described below.

For the study of organizational commitment this study is based on the proposal of Meyer and Allen because it is a theoretical proposal that is mostly used in Latin America (Scielo-Latindex 2020).

\subsubsection{Meyer and Allen's Theory and Model of Organizational Engagement}

Organizational commitment includes different approaches. This study is based on the theory of Meyer and Allen and its three components of organizational commitment. Like Meyer and Allen (1997), they identify affective commitment, permanence commitment, and normative commitment; affective commitment refers to emotional attachment, identification, and involvement with the organization; continuity (permanence) commitment emphasizes the cost that it would represent for the individual to leave/abandon the organization; and normative commitment refers to the individual's feeling of obligation to remain in the institution (Blanco and Castro, 2011).

Table 1. Organizational Commitment of Meyer and Allen

\begin{tabular}{l|l|l}
\hline Continuity & Normative & Affective \\
\hline Guidance, based on cost and need & Obligation or moral responsibility & Affective obligation, desire \\
Bond, result of investments over time / & $\begin{array}{l}\text { Moral obligation, developed by the } \\
\text { Few employment alternatives. }\end{array}$ & $\begin{array}{l}\text { Psychological rewards. Emotional } \\
\text { benefits by the organization. }\end{array}$ \\
\hline
\end{tabular}

Source: Meyer and Allen (1991).

\subsubsection{Organizational Commitment Model}

The organizational commitment model of Caykoylu, Egri, Havlovic and Bradley (2011), raises seven causes related to empowerment, motivation, identity, trust, ambiguity and conflict, which affect commitment through satisfaction. 


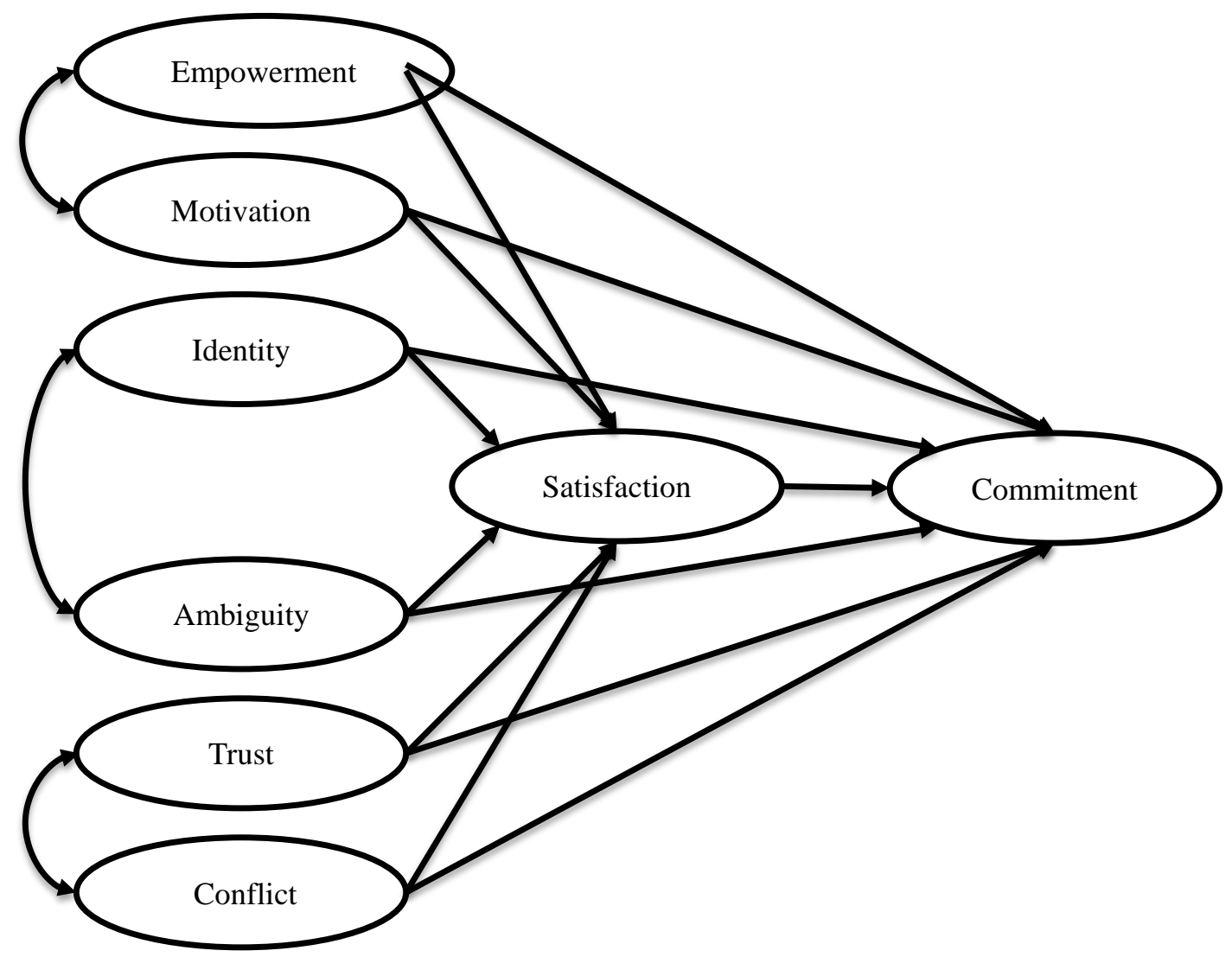

Figure 1. Organizational commitment model

Source: Caykoylu, Egri, Havlovic and Bradley (2011).

This model proposes that the relationship between job satisfaction and organizational commitment is better understood by focusing on the three interrelated facets of job satisfaction, i.e., satisfaction with professional promotion, satisfaction with the supervisor and satisfaction with co-workers. However, the model also advances that these facets of job satisfaction have different mediating effects for other organizational commitment antecedents.

It is said that increased empowerment and motivation would lead to increased satisfaction and commitment. However, the reduction of ambiguity and conflict, as they are negatively related to satisfaction, leads to an increase in commitment. Rather, increased identity and confidence also influence satisfaction and commitment (Hermosa, 2006). If organizational commitment is determined by empowerment, motivation, identity, trust, ambiguity and conflict through satisfaction, then commitment can be defined as the result of the interrelationship between organizational factors of human order in reference to the relationship between leaders and employees. In this sense, commitment is a function of personal desires and organizational visions; it is an indicator of equity and justice in which leaders relate to employees based on a balance between freedoms, capabilities and responsibilities.

\subsubsection{Frederick Herzberg's Two-Factor Theory (1959)}

For the purposes of this job satisfaction study, this theory is basic. One of the most accepted models is the Herzberg Theory of Hygiene and Motivation or the Herzberg Two-Factor Theory (1959, at Veličković, et al., 2014).

According to Martínez Aguilá and González Perarnau (2008), for Herzberg there are two factors that guide people's behavior. The hygienic factors or extrinsic factors, these are located in the environment of people, also contains those conditions for which they perform their work. These conditions are managed and decided only by the company, which means that the hygienic factors are alien to the decisions of the employees. 
The main hygiene factors are: salary, social benefits, the type of direction or supervision that people receive from their superiors, the physical and environmental conditions of work, the policies and guidelines of the company, the climate of relations between the company and the people who work there, internal regulations, etc. These are contextual factors and are located in the external environment surrounding the individual. Herzberg emphasized that traditionally only hygienic factors were taken into account in employee motivation: in the past, work was considered an unpleasant activity and in order to make people work more it was necessary to appeal to rewards and salary incentives, democratic leadership, open and stimulating company policies, meaning incentives placed externally to the individual in exchange for his or her work. Moreover, others encouraged people to work through rewards (positive motivation) or penalties (negative motivation).

According to Herzberg's research, when hygiene factors are optimal, they only prevent employee dissatisfaction, because they do not manage to consciously raise satisfaction, and when they do raise it, they do not manage to sustain it for long. However, when the hygienic factors are bad or precarious, they cause the dissatisfaction of the employees. Because of this more dissatisfaction-oriented influence, Herzberg calls them hygienic factors, because they are essentially prophylactic and preventive: they only prevent dissatisfaction, but do not cause satisfaction. Their effect is similar to that of certain hygiene remedies: they prevent infection or fight headaches, but do not improve health. Because they are more related to dissatisfaction, Herzberg also calls them unsatisfactory factors.

Motivational factors, or intrinsic factors, are related to the content of the position and the nature of the tasks that man executes. As such, the motivational factors are under the control of the individual, as they are related to those he does and performs. Motivational factors involve feelings of individual growth, professional recognition, and needs for self-fulfillment and depend on the tasks that the individual performs in his work. Traditionally, tasks and positions have been designed and defined with the sole concern of attending to the principles of efficiency and economy, suppressing the aspects of challenge and opportunity for individual creativity. With this, they lose psychological meaning for the individual who performs them and have a "de-motivation" effect, causing apathy, disinterest and lack of psychological sense, since the company does not offer anything beyond a decent place to work.

Job satisfaction is a function of the content or the challenging and stimulating activities of the position the person holds: these are the motivational or satisfying factors. Dissatisfaction in the position is a function of the context, that is, the work environment, the salary, the benefits received, the supervision, the colleagues and the general context surrounding the position held: these are the hygienic or unsatisfactory factors (Martínez Aguilá and González Perarnau, 2008).

Table 2. Factors encompassing Motivation and Hygiene according to Herzberg

\begin{tabular}{ll}
\hline \multicolumn{1}{c}{ Motivation } & \multicolumn{1}{c}{ Hygiene } \\
\hline Acomplishment & Policies and administration \\
Recognition & Supervision \\
Position or role that perform & Labor conditions \\
Promotion & Interpersonal relationships \\
Personal growth & Salary \\
& Security \\
& Personal life \\
\hline
\end{tabular}

Source: Own elaboration from the reading of (Herzberg, 1959).

\section{Methodology and Results}

\subsection{Methodology}

This section describes the methodology used in the diagnosis of the type of Organizational Commitment (OC) in the three dimensions proposed by the Meyer and Allen model, and the level of Job Satisfaction (SL) by identifying the motivational factors and the hygienic factors based on the theory of the two factors of Herzberg, which are present in the sample of the workers of the SAC.

The research that was carried out is of a descriptive type; the respective questionnaires were applied to evaluate each study (CO and FS).

\subsection{Population and Sample}

For this research, the population is made up of 82 trusted employees of the Central Academic Secretary of a Higher Education Institution in Cuernavaca, Morelos. 
Type of population: finite ( 82 employees).

Sample: 59 participants.

For this purpose, the interval estimation formula was applied for a population mean having a small sample, obtaining that, for the sample size of 59 participants from a total population of 82, the margin of error is 0.30726917 people and the $95 \%$ confidence interval goes from 1.697099679 to 1.082561338 people. In other words, the sample size is adequate for the size of the population studied.

\subsection{Measuring Instruments}

In order to evaluate the types of organizational commitment, the OCQ questionnaire instrument by Meyer, Allen, and Smith 1993 (revised version) was used.

The scale of emotional commitment evaluates the emotional attachment and identity with the labor area, the scale of normative commitment determines the obligation and responsibility that the subject has with the organization; finally, the scale of commitment of continuity evaluates the need for permanence with respect to the costs or investments that the worker makes in the company and the availability of other sources of work. The three scales expose the relationship with the worker's continuity in the organization.

The test of organizational commitment that was applied to the personnel of confidence of the Academic Secretary of the IES in Cuernavaca, Morelos, consists of 24 items in the Likert scale, distributed as follows:

- Affective Commitment: 8 Items

- Commitment to continuity: 8 Items

- Normative Commitment: 8 Items

Of which, the approaches are positive and/or negative.

For the analysis of the data it was taken into account that the answers to the negative approaches would be inverted by the proportionally opposite value in the scale, so if the respondent answers that he or she totally disagrees the inverted answer will be that he or she totally agrees.

In order to answer the questionnaire, trusted staff had to choose one of the seven points of a Likert scale distributed as follows:

Table 3. Likert's criteria

\begin{tabular}{ccccccc}
\hline 1 & 2 & 3 & 4 & 5 & 6 & 7 \\
\hline $\begin{array}{c}\text { Totally } \\
\text { disagree }\end{array}$ & At variance & $\begin{array}{c}\text { Slightly } \\
\text { disagree }\end{array}$ & Undecided & $\begin{array}{c}\text { Slightly } \\
\text { agree }\end{array}$ & Agreed & $\begin{array}{c}\text { In total } \\
\text { agreement }\end{array}$ \\
\hline
\end{tabular}

Source: Own elaboration

\subsection{Labor Satisfaction}

In order to evaluate the level of job satisfaction, the OCQ questionnaire instrument of the Two-Factor Theory of Herzberg modified by Robbins "Motivation and Hygiene Factors according to Herzberg" was used.

The Two-Factor Model is made up of the hygienic factors or sources of job dissatisfaction (working conditions, company policies, supervision, co-workers) and the motivational factors or sources of job satisfaction (interest in work, responsibility, recognition, performance).

Similarly, to answer the questionnaire, the personnel of confidence had to choose one of the five points of a Likert scale distributed as follows:

Table 4. Likert's criteria.

\begin{tabular}{ccccc}
\hline 1 & 2 & 3 & 4 & 5 \\
\hline \multirow{2}{*}{ Totally disagree } & At variance & $\begin{array}{c}\text { Neither agreement nor } \\
\text { disagreement }\end{array}$ & Agreed & Strongly agree \\
\hline
\end{tabular}

Source: Own elaboration 


\subsection{Data Analysis}

For the purposes of this study, data was collected through the application of surveys (questionnaires) with the purpose of evaluating the information in a descriptive manner and identifying the factors that affect the trusted employees of the IES.

\subsection{Information Coding}

The coding of the answers produced by the trusted employees was done through the Excel 2016 program for Windows 10, converting the answers of each item of the instruments used, into numerical codes in order to group the answers and get the information for analysis and interpretation.

4.7 Results of the Elements that Cause Important Effects on the Types of Organizational Commitment of the Academic Secretary

Table 5. Leve lof Organizational commitment

\begin{tabular}{|c|c|c|c|}
\hline & Low & Medium & High \\
\hline Affective commitment & $37.92 \%$ & $7.84 \%$ & $54.24 \%$ \\
\hline Ongoing commitment & $33.47 \%$ & $13.77 \%$ & $52.75 \%$ \\
\hline Normative commitment & $38.98 \%$ & $19.07 \%$ & $41.95 \%$ \\
\hline
\end{tabular}

Source: Own elaboration based on results obtained from the tool application.

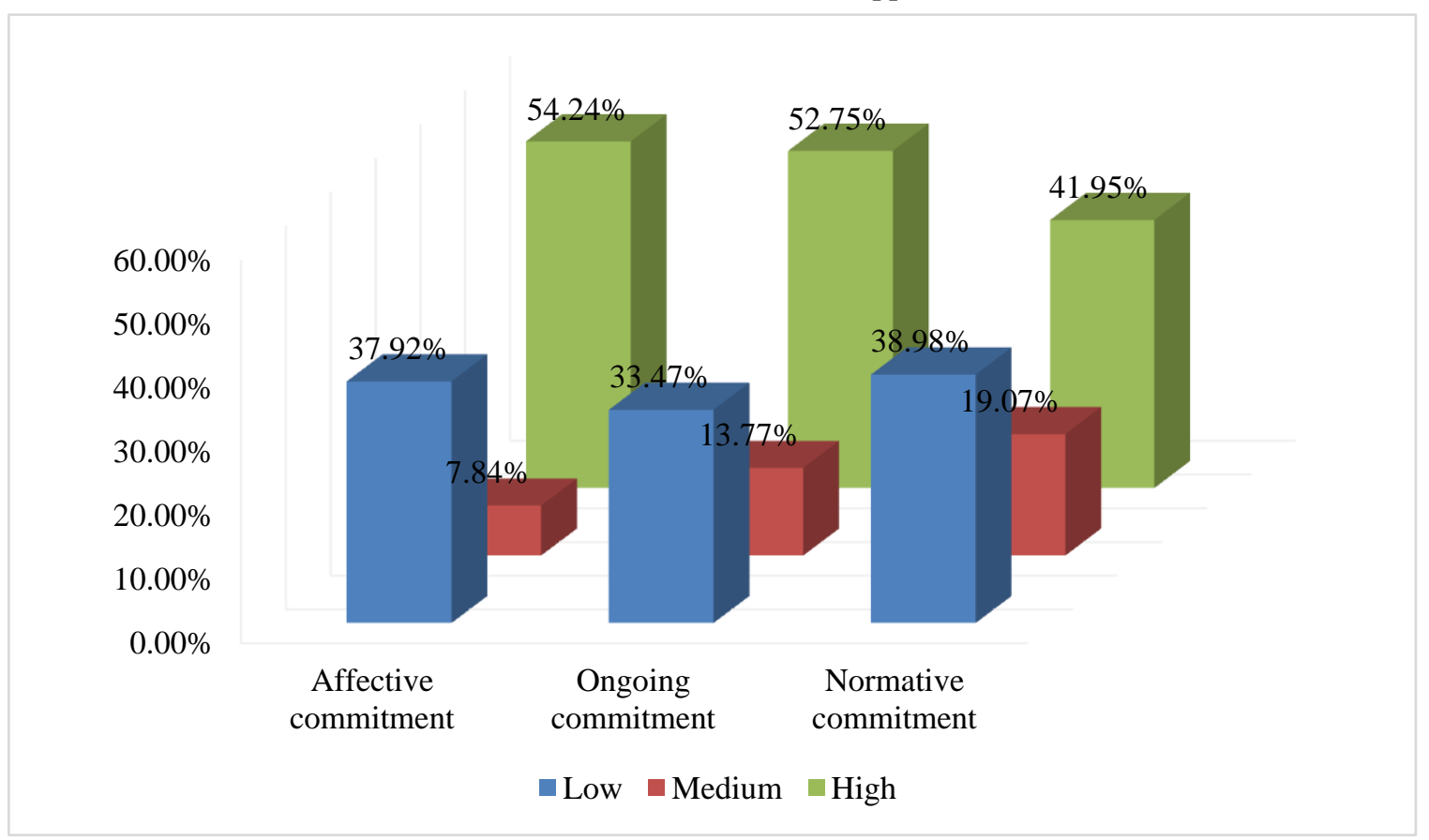

Figure 2. Level of Organizational Commitment

\subsubsection{Results Affective Engagement Scale}

The emotional commitment, is presented when a person feels happy and satisfied with what he is achieving within the place where he works, but above all that he remains stable and happy with those around him. For this, the statistical variables in this research are fundamental, since they are mediating in the most marked organizational commitment, that is, 54.24\% of trusted employees, affirm that the institution has a great personal meaning for them and expressed affective commitment; the emotional ties that were created within the institution, refer to the satisfaction of the needs and expectations at the moment of perceiving them in the appropriate way by the employees. As a whole, a type of commitment with emotional ties, feelings, desires, etc. was observed, as can be seen in Figure 2.

The most important characteristic detected in this group of workers is that feelings of belonging, affection and joy appear, they want to be in the institution, the type of psychological contract is relational (emotional bond), the values that this group of workers profess are of identification and congruence between values of the person and the organization, and the result that they obtain in the institution is acceptance of change, work satisfaction, initiative, cooperative spirit and desire of permanence. 


\subsubsection{Continuous Engagement Scale}

In figure 2 of the continuous commitment scale, it can be seen that $52.75 \%$ of trusted employees are in the institution because of a situation of need. Likewise, $33.47 \%$ of the employees state that their lives would be affected if they decided to leave the institution at this time. Likewise, $13.77 \%$ responded that working for the institution requires a high level of personal sacrifice and other employment could not match the general benefits they receive. Their commitment is a relationship of sharing needs, where you give me your effort and I pay you.

Within this type of commitment, reference is made to the recognition of a person's work, emphasizing the few opportunities to find another job, should he or she decide to leave the institution. This makes him aware of the effort and time he has invested to maintain his current position. This results in the employee's attachment to the institution, to coming to the conclusion that there are few opportunities outside of it.

The main characteristic is that he feels obliged by the salary he receives, his judgment is more rational based on the fact that he "has" to be in the institution, it is a type of transactional psychological contract, that is, costs linked to membership.

\subsubsection{Regulatory Commitment Scale}

Regarding the normative commitment, it was observed that $41.95 \%$ of the trusted employees base their commitment on the intervention of their values. The human resource lives with the idea that it should and must be in the company because she was the only one who gave it the opportunity. It was noted that $38.98 \%$ agreed that a person should always be loyal to his employer. Evidently, $19.07 \%$ agree that it is unethical or immoral to jump from one job to another; this indicates the feeling of loyalty and the sense of moral obligation to remain in the institution.

This type of commitment emphasizes "duty", that is, the values and culture of a person within the institution; loyalty to the institution as a token of payment for those benefits he or she may receive, which will make the trusted employee feel part of it.

The main characteristic of this group of workers is loyalty, to feel that they are obligated. Here, the worker is determined to contribute to the institution's goals, the firm determination to be loyal is developed. Moral duty where there is no need for the emotional to be present.

When these results are combined with the work satisfaction variable, added to the variables of gender, years in service, age, work contract condition, academic level, among others, the type of commitment can be observed; one would have a component that according to Meyer is the degree of conformity of the person with respect to his or her work environment: Happiness at work, since these determine the type and level of commitment in the organization.

The link that forms the worker with the institution has been studied, recognizing the organizational commitment as a critical predictor of the work performance of the IES employees.

\subsection{Results of the Factors that Impact the Job Satisfaction of the Academic Secretary.}

According to the theoretical model proposed, the elements measured in this research are described in the following figure, work satisfaction. 


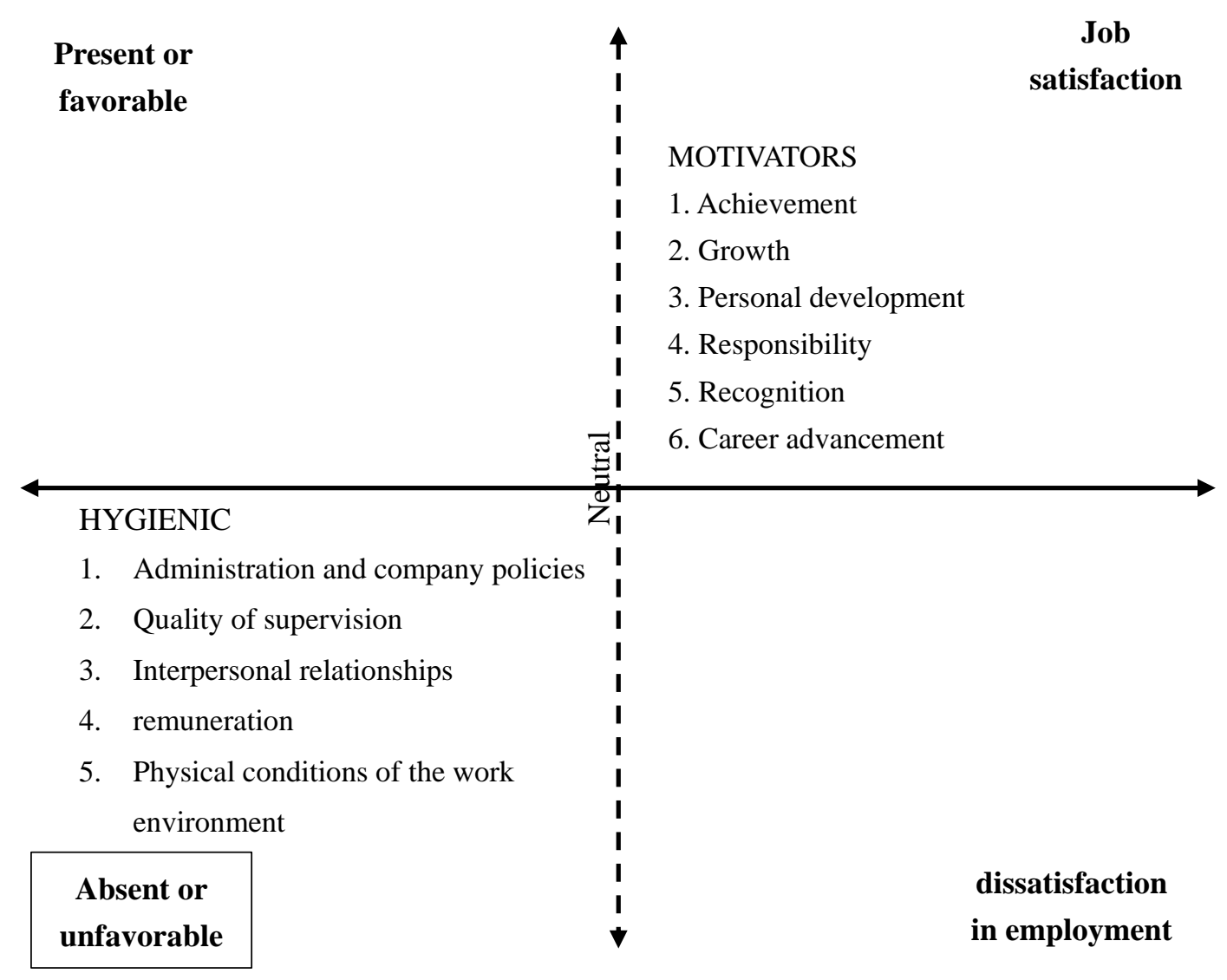

Figure 3. Degree of agreement on the interpretation of the sub-factors based on the Motivation-Hygiene Theory or Bifactorial Theory

Source: Own elaboration based on the proposal of Frederick Irving Herzberg.

Here are the most demonstrative values of the study, the midpoint (neutral) for this case study, as shown in Figure 3, is $50 \%$. Then, from what we can reflect from the data obtained from the application of the instrument, it is observed that $98 \%$ of the employees of confidence declare to have good interpersonal relations. Likewise, $92 \%$ of the employees consider that their work contributes directly to the achievement of the objectives. Likewise, $89 \%$ revealed that they feel satisfied with their working hours. Also, $77 \%$ feel free to perform their work according to their criteria and consider that their bosses create an atmosphere of trust, are accessible and that it is easy to talk to them. However, we found hygienic factors that determine the existence of dissatisfaction in employment such as that $47 \%$ expressed disagreement with the rewards and/or incentives they receive and 32\% exposed, disagreeing with the remuneration they receive for the work they do.

This is supported by the approaches of Herzberg, Mausner and Snyderman (1959) in which they describe:

"poor working conditions, poor management of the company and an erroneous management style will normally determine dissatisfaction at work. Good policy, administration, management style or working conditions will not in themselves determine satisfaction. On the contrary, recognition, achievement, interesting work, responsibility, and promotion determine job satisfaction, while their absence rarely leads to satisfaction" (pp. 65-66).

In other words, those factors that determine job satisfaction are different from those that produce dissatisfaction (Herzberg, 1968). The determining factors of great satisfaction, called by Herzberg, Mausner and Snyderman (1959) motivating factors, are based on the content of the work itself, while the factors that produce dissatisfaction, called by Herzberg, Mausner and Snyderman (1959) hygiene factors, refer to the conditions in which the work is performed. 
These results represent a moderate level of satisfaction, therefore, the trusted employees of the SAC are moderately satisfied, a situation that can be improved through strategies that bring satisfaction to more considerable levels.

\section{Conclusions}

Two specialized instruments were applied to identify the level of organizational commitment and labor satisfaction. Based on the Meyer and Allen model and the Theory of two factors by Herzberg. Both allowed to identify elements that affect the study variables. Likewise, those factors that help satisfaction and identify with other that determine dissatisfaction were identified. Similarly, types of commitments that exist in organizations were exposed. Altogether, the findings gave an overview of the actual situation of the institution and this allows development on an organizational intervention program, for a better labor development.

\subsection{Proposals for Improving the Employment Situation of Trusted Employees}

- To constitute a better salary scale by means of a study that takes as reference the levels of salary of the sector in the local, regional and national scopes or to offer another benefit, different from the economic perception, that is of the interest of the employee, for example: a day of rest in the month with salary, courses, etc.

- Establish a better form of selection and hiring.

- Develop a career plan.

- Maintain clear policies and communicate them to all employees.

- Carry out trainings aimed at introducing and strengthening institutional values.

- Avoid administration by gossip and give the communications in an official way.

- Strengthen internal promotion.

- Develop and implement a work enrichment program, for which it is important to make a diagnosis of the number and complexity of the tasks and functions of the positions. Such a program implies strategically defining to which positions are added the most demanding and complex functions and tasks, as well as other functions of equal complexity inherent to the position.

- To establish a medium and long term training program, which contemplates training in subjects that allow them to improve their work performance;

- Support with scholarships and access permits for employees who are interested in training at the specialization, master's and doctorate levels, which will allow them to have better opportunities within the company.

- To develop an Institutional Program of Organizational Development, which allows to measure the organizational factors in the University in a periodic way.

\section{References}

Aguirre, C., Andrade, M., \& Castro, A. (2005). Desarrollo de un instrumento de variables que podrían influir en la satisfacción laboral de trabajadores de la construcción en Santiago de Chile. Revista de la Construcción, 4, 81-90.

Allen, N., \& Meyer, J. (1990). The measurement and antecedents of affective, continuance and normative commitment to the organization. Journal of Occupational Psychology, 1-18. https://doi.org/10.1111/j.2044-8325.1990.tb00506.x

Becker, T. (1992). Foci and Bases of Commitment: Are They Distinctions Worth Making? Academy of Management Journal, 232-244. https://doi.org/10.5465/256481

Blanco, M., \& Castro, P. (2011). Análisis comparativo del compromiso organizacional manifestado por madres y mujeres sin hijos. Ajayu.

Casaux, C. (24 de Agosto de 2015). Prezi. Obtenido de. Retrieved from https://prezi.com/ueschpjavtf7/escuela-del-comportamiento-organizacional/

Castillo, A. (2006). Estadística Aplicada: Población, muestra y datos, Variables cualitativas y cuantitativas e Hipotésis estadísticas. Trillas.

Caykoylu, S., Egri, C., Havlovic, S., \& Bradley, C. (2011). Key organizational commitment antecedents for nurses, paramedical professionals. Journal of Health Organization and Management, 7-33. https://doi.org/10.1108/14777261111116806

D' Alessio, F. (2015). El proceso Estratégico: Un enfoque de gerencia. Lima: PEARSON.

Davis, K., \& Newstrom, J. (1999). Comportamiento Humano en el Trabajo. México: McGraw Hill.

Dessler, G. (1991). Administración de personal. Madrid: Prentice Hall International.

Eagly, A., \& Chaiken, S. (1993). The Psychology of Attitudes. Fort Worth, TX.: Harcourt Brace Jovanovich College Publ. 
Figuereido, H., Grau, E., Gil, P., \& García, J. (2012). Síndrome de quemarse por el trabajo y satisfacción laboral en profesionales de enfermería. Psicothema, 271-276.

Giacalone, R., \& Jurkiewicz, C. (2010). Handbook of Workplace Spirituality and Organizational Performance. M.E. Sharpe. https://doi.org/10.4324/9781315703817

Hermosa, R. (2006). Satisfacción laboral y síndrome de Burnout en profesores de educación primaria y secundaria. Revista Colombiana de Psicología.

Herzberg, F. (1968). One more time: How do you motivate employees? Harvard Business Review, 53-62.

Herzberg, F., Mausner, B., \& Snyderman, B. (1959). The Motivation to Work. New York: John Wiley \& Sons.

Hodgetts, R., \& Altman, S. (1985). Comportamiento en las organizaciones. México: Interamericana.

Jongsoon, J. (2016). The role of assessment centers in job satisfaction and organizational commitment: a case of the Korean government. The International Journal of Human Resources Management.

Locke, E. (1976). The nature and causes of job s atisfaction. Chicago: 1297-1343.

Manso, P. J. (2002). El legado de Frederick Irving Herzberg. Universidad EAFIT, 79-86.

Martínez, A. M., \& González Perarnau, R. (20 de Octubre de 2008). ¿Me siento bien en mi trabajo? Satisfacción laboral de las enfermeras de la Xarxa Sanitaria I. Santa Tecla, Salvador.

Maslow, A. (1970). Motivation and personality. New York: New York: Harper \& Row.

Meyer, J., \& Allen, N. (1991). A three-component conceptualization of organizational commitment. Human Resource Management Review, 61-89. https://doi.org/10.1016/1053-4822(91)90011-Z

Meyer, J., \& Allen, N. (1997). Commitment in the Worplace: Theory, Research, and Application. Advanced Topics in Organizational Behavior.

Mowday, R., Porter, L., \& Steers, R. (1982). Employee-Organization Linkages: The Psychology of Commitment, Absenteeism, and Turnover. New. https://doi.org/10.1016/B978-0-12-509370-5.50005-8

Peiró, J. (1996). Psicología de la Organización. Madrid: Universidad Nacional de Educación a Distancia.

Pérez, E., Rivero, L., \& Samino, R. (2009). Administrando en entornos inciertos. XXIII Congreso anual AEDEM. Teorías de la motivación humana aplicadas al ámbito de la venta personal.Libro de Ponencias. XXIII Congreso Anual de la Academia Europea de Dirección y Economía de la Empresa (págs. 1-19). Sevilla: ESIC.

Porter, L., Steers, R., Mowday, R., \& Boulian, P. (1974). Organizational commitment, job satisfaction, and turnover among psychiatric technicians. Journal of Applied Psychology, 603-609. https://doi.org/10.1037/h0037335

Ramírez, R., Abreu, J., \& Badii, M. (2008). La motivación laboral, factor fundamental para el logro de objetivos organizacionales: caso empresa manufacturera de tubería de acero. International Journal of Good Conscience, 143-185.

Robbins, S. P., \& Judge, T. A. (2009). Comportamiento Organizacional. México: Pearson Education.

Robbins, S., \& Coulter, M. (2012). Administración. New Jersey: Prentice Hall.

Spector, P. (1997). Job Satisfaction: Application, Assessment, Causes and Consequences. Thousand Oaks: Sage Publications. https://doi.org/10.4135/9781452231549

Veličković, V., Višnjić, A., Jović, S., Radulović, O., Šargić, C., \& Mihajlović, J. M. (2014). Organizational Commitment and Job Satisfaction Among Nurses in Serbia: A Factor Analysis. Nursing Outlook. https://doi.org/10.1016/j.outlook.2014.05.003

Vroom, V., \& Deci, E. (1979). Motivación y alta dirección. México: Trillas.

Zeynep, Y., Rayton, B., \& Rapti, A. (2017). Facets of job satisfaction and work engagement. Evidence-based HRM: A Global Forum for Emprirical Scholarship, 248-265. https://doi.org/10.1108/EBHRM-08-2015-0036

\section{Copyrights}

Copyright for this article is retained by the author(s), with first publication rights granted to the journal.

This is an open-access article distributed under the terms and conditions of the Creative Commons Attribution license which permits unrestricted use, distribution, and reproduction in any medium, provided the original work is properly cited. 